\title{
Farklı Hücre Dizilerinde 808 nm Laser Uygulaması ve DNA Sentezi
}

\author{
Ayşe $\mathrm{AK}^{1 *}(\mathbb{0}$ \\ ${ }^{1}$ Kocaeli Üniversitesi, Kocaeli Sağlık Meslek Yüksekokulu, Tıbbi Hizmetler ve Teknikler Bölümü, Tıbbi \\ Görüntüleme Teknikleri Programı, Kocaeli/Türkiye
}

Geliş / Received: 03/12/2019, Kabul / Accepted: 30/12/2019

$\ddot{O} \mathbf{z}$

Fotodinamik Terapi (FDT), kanser tedavisinde lokal olarak kullanılan ve yan etkileri minimum düzeyde olan non-invazif bir yöntemdir. FDT bileşenlerinden biri olan fotosensitizan ajan, uygun dalga boyuna sahip 1şıkla birlikte kanserli hücrelerde reaktif oksijen türlerinin ve/veya singlet oksijen radikallerinin üretimini uyarır. Kullanılan ışık kaynağının ve fotosensitizan ajanın tek başına bir toksik etkisinin olmadığı bildirilmektedir. Ancak yapılan çalışmaların bir kısmında sadece laser uygulamalarının hücre dizilerinde etkilere sahip olabileceğine dair yayınlar da mevcuttur. Bu amaçla sıklıkla çalışılan hücre dizileri olan C6 glioma, Caco-2 kolon kanseri, L929 fibroblast ve prostat kanseri PC-3 hücre dizilerinde, $808 \mathrm{~nm}$ dalga boyuna sahip $50 \mathrm{~J} / \mathrm{cm}^{2}$, $100 \mathrm{~J} / \mathrm{cm}^{2}, 150 \mathrm{~J} / \mathrm{cm}^{2}$ enerji yoğunluğundaki laser ışık kaynağının 24, 48 ve 72. saatlerdeki DNA sentezi üzerine etkileri araştırılmıştır. Laser uygulamasının, Caco-2 hücreleri hariç, diğer tüm hücre hatlarında 24. saatte DNA sentezini azalttığı, ancak bu etkinin diğer saatlerde kontrolden farklı olmadığı belirlenmiştir. Sonuç olarak, uygulanan laser dozuna ve hücre hattına bağlı olarak, laser uygulaması, kısa sürede, DNA sentezi üzerinde baskılayıcı etkilere sahip olabilse de, bu etkilerin diğer hücresel mekanizmalar bağlamında da araştırılması gerekmektedir.

Anahtar Kelimeler: DNA sentezi, hücre dizileri, 808nm laser

\section{8 nm Laser Application and DNA Synthesis in Different Cell Lines}

\begin{abstract}
Photodynamic Therapy (PDT) is a non-invasive method with minimal side effects in the treatment of cancer. The photosensitizing agent, one of the FDT components, stimulates the generation of reactive oxygen species and / or singlet oxygen radicals in cancer cells with light that is at appropriate wavelength. The light source and the photosensitizing agent alone are reported to have no toxic effect. However, in some of the studies, there are also reports that only laser applications can have effects on cell lines. For this purpose, effects of the $808 \mathrm{~nm}$ laser light source at $50 \mathrm{~J} / \mathrm{cm}^{2}, 100 \mathrm{~J} / \mathrm{cm}^{2}$ and $150 \mathrm{~J} / \mathrm{cm}^{2}$ were investigated DNA synthesis of C6 glioma, Caco-2 colon cancer, L929 fibroblast and prostate cancer PC-3 cell that are frequently studied. It was found that except for Caco-2 cells, laser application decreased DNA synthesis in all other cell lines at 24 hours, but this effect was maintained at other hours. As a result, although laser application may have effects on DNA synthesis at short time depending on the dose and cell line used, these effects should be investigated in the context of other cellular mechanisms.
\end{abstract}

Keywords: DNA synthesis, cell lines, $808 \mathrm{~nm}$ laser 


\section{Giriş}

Geleneksel kanser tedavilerinin yetersiz kalabildiği günümüzde yeni terapi arayışları ivme kazanmıştır. Laser 1şığı ile etkileşen bir fotosensitizan varlığında serbest radikal üretimi esasına dayalı sitotoksisiteye neden olan Fotodinamik Terapi (FDT) uygulamas1 özellikle yüzeysel kanserlerin tedavisinde başarılı olmaktadır (Oniszczuk et al., 2016, Topaloğlu et al., 2015). Laser 1şığı uygun dozda uygulandığında hücre ve dokularla etkileşerek, uygulanan doza, zamana, hücrenin tipine ve redoks durumuna bağlı olarak hücresel fonksiyonlarda değişimlere neden olabilmektedir (Zecha et al., 2016). FDT uygulamalarında kullanılan laser kaynağı hedeflenen dokudaki tümörü yok etmek için bir tetikleyici görev görmekte olup, kullanılan 1şı̆̆ın dalga boyu aralığı ise 600$800 \mathrm{~nm}$ arasında değişmektedir. $\mathrm{Bu}$ aralıkta tek başına kullanılan 1şık kaynağı derin doku tümörleri için yeterli toksik etkilere sahip olamamaktadır (Yu et al., 2017). Posten et al. (2005)'e göre laser uygulamasının düşük seviye kabul edilebilmesi için enerji yoğunluğunun $\quad 0,01-100 \quad \mathrm{~J} / \mathrm{cm}^{2}$ aralığında olması gerekmektedir. Literatürde farklı hücre dizilerinin, farklı ışı kaynaklarının ve farklı zaman aralıklarının kullanılmasına bağlı olarak uyumsuz sonuçlar mevcuttur. In vitro dizayn edilen bu çalışmada, birden çok hücre dizisinde, 3 farklı zaman noktasında ve birden fazla enerji yoğunluğu kullanılarak hücrelerin DNA sentezleri üzerindeki etkilerinin belirlenmesi hedeflenmiştir. $50-150 \mathrm{~J} / \mathrm{cm}^{2}$ enerji yoğunluklarındaki diyot laser uygulamasının derin doku tümörleri içinde yer alabilen beyin, kolon ve prostat kanserleri ve ayrica fibroblast hücre dizilerinin DNA sentezleri araştırılmıştır.

\section{Materyal ve Metot}

\section{Hücre dizileri kültürü}

Glioma C6 hücre dizileri, Caco-2 kolon kanseri hücre dizileri, L929 fibroblast hücre dizileri ve prostat kanseri PC-3 hücre dizileri $\% 10$ fetal bovin serum (FBS) içeren Dulbecco's Modified Eagle Medium (DMEM) besiyeri içinde $37^{\circ} \mathrm{C}, \% 5 \mathrm{CO}_{2}$ 'li inkübatörde kültüre edilerek yeterli sayıya ulaşmaları sağlanmıştır. Daha sonra hücreler tripsinazyon yardımıyla kaldırılıp gruplar oluşturularak laser uygulamalarına uygun hale getirilmiştir.

\section{Laser uygulaması}

Hücreler 96 kuyucuklu plakalara 2x $10^{4}$ hücre olacak şekilde ekimleri yapıldıktan sonra, kontrol grubu da dahil olmak üzere oluşturulan 4 grup (Kontrol, $50 \mathrm{~J} / \mathrm{cm}^{2}, 100$ $\mathrm{J} / \mathrm{cm}^{2}$ ve $150 \mathrm{~J} / \mathrm{cm}^{2}$ gruplar1) hücrelerin kuyucuklara oturması amaciyla 24 saat inkübasyona bırakılmıştır. 24 saatin sonunda $808 \mathrm{~nm}$ dalga boyuna sahip 1şıma yapabilen diyot laser kullanılarak, her plaka üzerinde yer alan hücre içerikli kuyucuklara $50 \mathrm{~J} / \mathrm{cm}^{2}, 100$ $\mathrm{J} / \mathrm{cm}^{2}$ ve $150 \mathrm{~J} / \mathrm{cm}^{2}$ enerji yoğunluğundaki uygulamalar yapılmıştır.

\section{DNA sentezinin ölçülmesi}

Çoğalmakta olan hücrelerin DNA sentezi sirasinda 5-Bromo-2'-deoxy-uridine (BrdU) inkorporasyonunu temel alan ve kolorimetrik ölçüm yapabilen Cell Proliferation ELISA, BrdU (colorimetric) Roche (Cat No: 11647 229 001) kiti kullanılmıştır. Hücrelerin kuyucuklara ekimi ve laser uygulaması sonras1 hücreler BrdU ile işaretlenmiş, FixDenat solüsyonu ile inkübe edilmiştir. İnkübasyondan 30 dakika sonra $100 \mu \mathrm{l}$ antiBrdu POD ile inkübasyona bırakılmıştır. 90 dakika sonra kuyucuklar kit içeriğinde gelen yıkama solüsyonu ile yıkanmıştır. $100 \mu \mathrm{l}$ substrat solüsyonun eklenmesi ve inkübasyon 
neticesinde renk gelişimi gözlenmiştir. Renk gelişiminin durdurulması amaciyla $25 \mu 11 \mathrm{M}$ $\mathrm{H}_{2} \mathrm{SO}_{4}$ kullanılmıştır. $450 \mathrm{~nm}$ dalga boyuna sahip mikroplate okuyucu (iMark, Bio-Rad., USA) kullanılarak absorbans okumas1 yapılmıştır.

\section{İstatistiksel analiz}

Elde edilen normalize veri grupları arasında istatistiksel farkı belirlemek için One Way ANOVA testi ve gruplar arasındaki fark1 belirlemek için Tamhane testi (SPSS Statistic Viewer V22.0) kullanılmıştır. Anlamlılık derecesi $\% 5(p<0,05)$ olarak değerlendirilmiş ve tüm deneyler 2 tekrar olacak şekilde yapılmıştır.

\section{Bulgular}

Şekil 1'de görüldüğü üzere, C6 glioma hücre dizilerinde, istatistiksel olarak anlaml belirlenmemiş olsa da, 72. saat sonunda 100 ve $150 \mathrm{~J} / \mathrm{cm}^{2}$ enerji yoğunluğu uygulamasının, DNA sentezinde kontrole göre artış gösterdiği görülmektedir. C6 hücre dizilerinde DNA sentezinin 24.saatte diğer enerji yoğunlukları ile karşılaştırıldığında $150 \mathrm{~J} / \mathrm{cm}^{2}$ uygulaması ile azaldığı $(p<0.05)$ görülmektedir (Şekil 2).

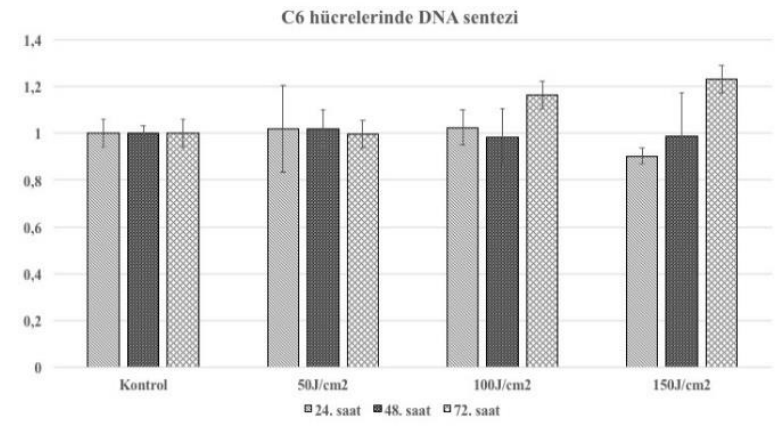

Şekil 1. C6 glioma hücre dizilerinde 24, 48 ve 72. saat sonunda laser uygulamasının DNA sentezine etkileri
24. saatte C6 hücrelerinde DNA sentezi

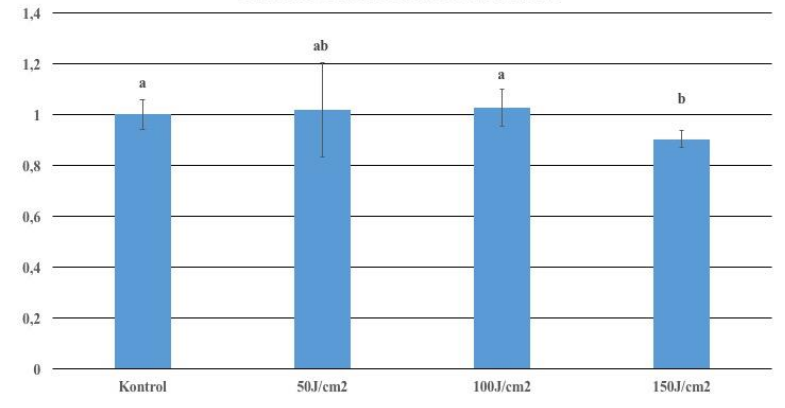

Şekil 2. C6 glioma hücre dizilerinde 24. saat sonunda DNA sentezi $(\mathrm{p}<0,05)$

Caco-2 kolon kanseri hücre dizilerinde uygulanan enerji yoğunluklarının hiç birisi DNA sentezinde istatistiksel olarak etki göstermezken, 72 saat sonunda tüm enerji yoğunluklarının az da olsa DNA sentezini tetiklediği gözlenmektedir (Şekil 3).

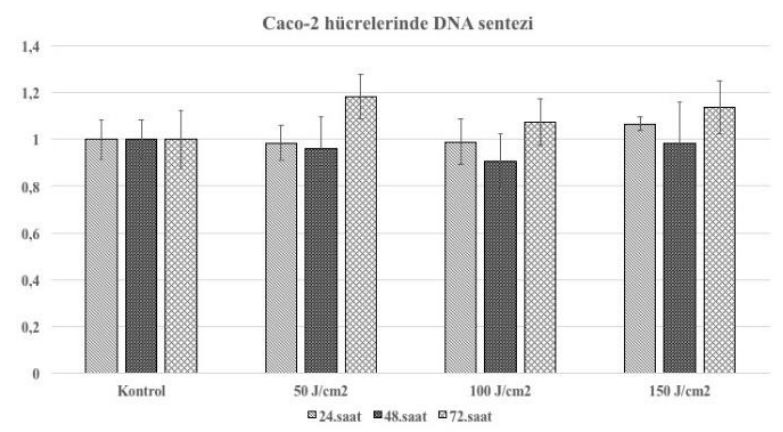

Şekil 3. Caco-2 kolon kanseri hücre dizilerinde 24,48 ve 72 . saat sonunda laser uygulamasının DNA sentezine etkileri

Fibroblast hücre dizilerindeki uygulamalar neticesinde ise, her ne kadar istatistiksel olarak anlamlı olmasa da Şekil 4'de görüldüğü üzere, uygulamadan 48 saat sonra tüm enerji yoğunluklarının kontrole göre DNA sentezinde artışa sebep olduğu, ancak 72 saat sonunda kontrolle benzer değerlere ulaştığı görülmektedir (Şekil 4). 


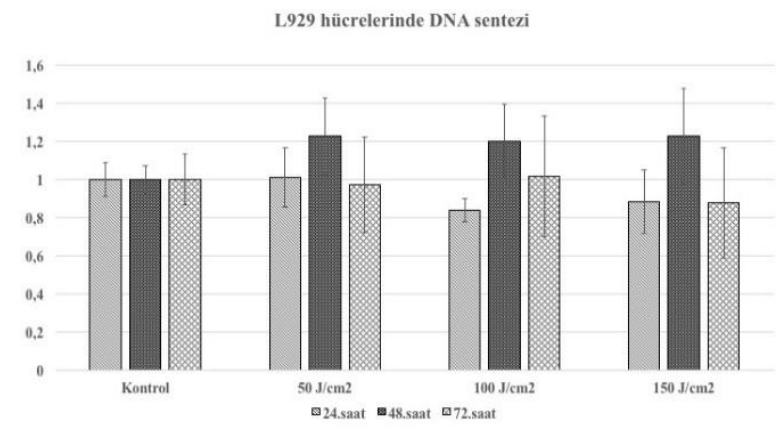

Şekil 4. L929 fibroblast hücre dizilerinde 24, 48 ve 72 . saat sonunda laser uygulamasinın DNA sentezine etkileri

24 saat sonunda ise $100 \mathrm{~J} / \mathrm{cm}^{2}$ enerji yoğunluğunun kontrole göre istatistiksel olarak anlamlı şekilde DNA sentezinde azalışa $(\mathrm{p}<0,05)$ sebep olduğu görülmektedir (Şekil 5).

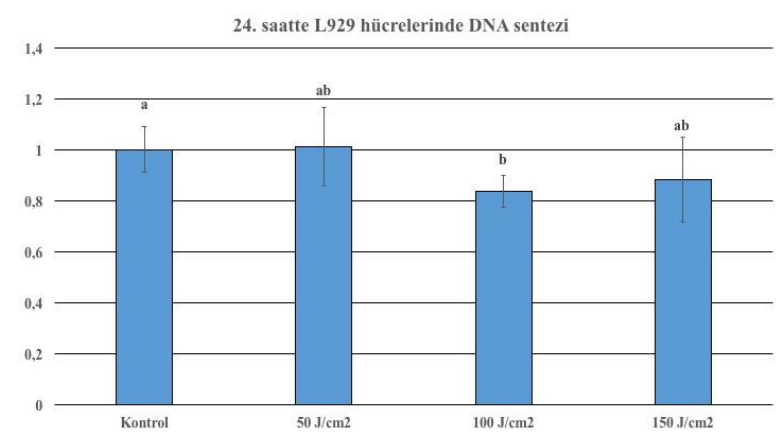

Şekil 5. L929 fibroblast hücre dizilerinde 24. saat sonunda DNA sentezi $(p<0,05)$

Prostat kanser hücre dizileri PC-3 hücrelerinde ise, $150 \mathrm{~J} / \mathrm{cm}^{2}$ uygulamasinın 24 saat sonunda, istatistiksel olarak anlaml olmasa da, kontrole göre DNA sentezinde azalışa sebep olduğu ve diğer zaman noktalarında hücrelerin DNA sentezleri görülmektedir (Şekil 6).

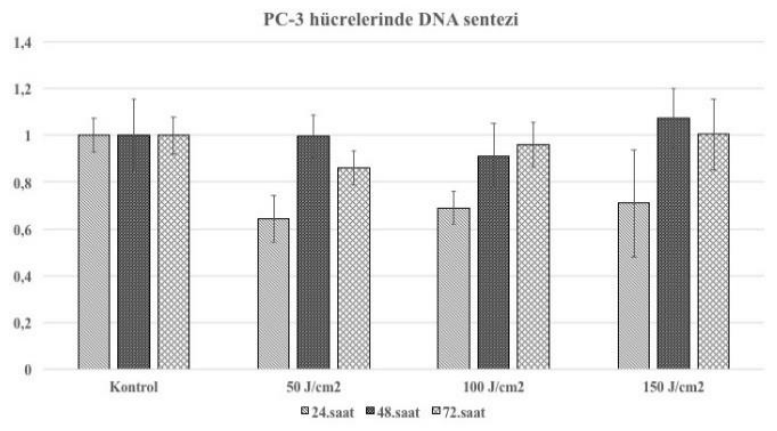

Şekil 6. PC-3 prostat hücre dizilerinde 24, 48 ve 72 . saat sonunda laser uygulamasının DNA sentezine etkileri

Şekil 7'de de görüldüğü üzere, 24 saat sonunda 50 ve $100 \mathrm{~J} / \mathrm{cm}^{2}$ enerji yoğunluk uygulamaları, istatistiksel olarak anlamlı şekilde, kontrole göre DNA sentezinde azalışa $(p<0,05)$ sebep olmuştur.

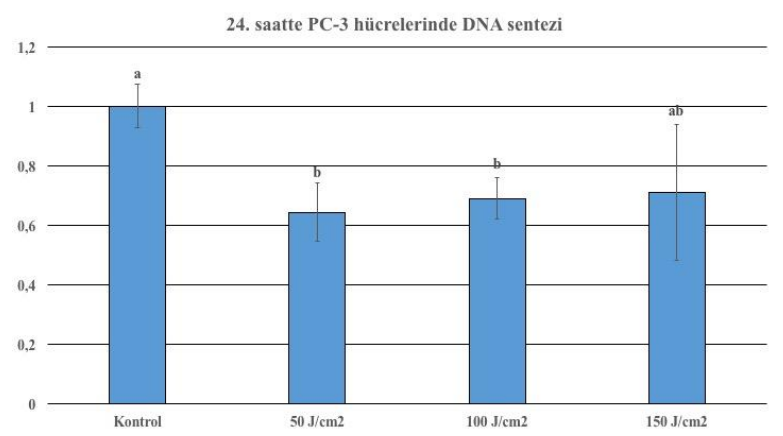

Şekil 7. PC-3 prostat kanseri hücre dizilerinde 24. saat sonunda DNA sentezi $(\mathrm{p}<0,05)$

\section{Sonuç}

Yapılan bu çalışmada, Caco-2 hücreleri hariç olmak üzere, diğer hücrelerin uygulama gruplarının 24 saat sonunda DNA sentez seviyeleri etkilenmekle birlikte, 72 saatin sonunda bu etkilerin kontroldekilerle benzer olduğu gösterilmiştir. Farklı orjinlerden gelen hücre dizileri kendine özgü cevaplar geliştirmiş, farklı enerji yoğunluk uygulamalarında farklı DNA sentez oranları belirlenmiştir. Laser uygulamasının, 24 saat sonunda kanser hücrelerindeki DNA sentezlerinin azalmasına sebep olduğu, 
dolayısıyla hücre çoğalmasına etkisi olabileceği düşünülebilir.

Daha önce de bahsedildiği üzere, yapılan uygulamalar laserin dalga boyu, enerji yoğunluğu, hücre tipi ve kanser evrelerine göre farklı sonuçların alınmasına sebep olabilmektedir. Üstelik, çeşitli klinik denemelerde benzer şekillerde kullanılan enerji yoğunlukları aynı olsa bile, laserin gücü gibi özelliklerine bağlı olarak da hücrelerin cevapları değişebilmektedir (Schartinger et al., 2012, AlGhamdi et al., 2012).

25-400 J/cm² enerji yoğunluğunun uygulandığ 1 U251 glioma hücre dizilerinde, sadece en yüksek uygulamanın hücresel yaşam oranı CCK-8 üzerinde olumsuz yönde etkileri olduğu bildirilirken (Xu et al., 2010), klinik çalışmalarda kullanılan laser parametreleri ile yapılan in vitro bir çalışmada, KG-1 hücre büyümesinin farklı laser uygulamalarına göre farklı cevaplar verdiği, en yüksek enerji yoğunluğuna sahip uygulamanın hücrelerin çoğalmasına neden olduğu belirlenmiştir (Dastanpour et al., 2015)

Benzer şekilde, Ottaviani et al. (2016)'nın da yaptığı çalışmada, farklı dalga boylarında $(660 \mathrm{~nm}-970 \mathrm{~nm})$ ve enerji yoğunluklarındaki (3-6 J/ $\mathrm{cm}^{2}$ ) uygulamaların 24 saat sonunda in vitro farklı hücre dizilerinin metabolizma ve çoğalmasını artırdığı, ancak bu etkinin 48.saatteki ölçümlerde istatistiksel olarak farklı olmadığını bildirmişlerdir. Ayrıca in vivo yapılan deneylerde de in vitro elde edilen sonuçların tersine tümör büyümesini azalttığını belirlemişlerdir.

Meme adenokarsinoma hücresi MCF-7, duktal karsinoma hücresi MDA-MB-435S ve immortal meme epitel hücreleri üzerinde yapılan çoklu laser uygulamalarının $(780 \mathrm{~nm}$, 830nm ve 904nm) sadece MCF-7 hücrelerinin çoğalmasına neden olduğu, ancak laserin tekrarlı şekilde uygulanması neticesinde hiçbir hücre dizisinin malignant karakter kazanmadığı bildirilmiştir (Powell et al., 2010).

Larinks kanser hücre dizilerinde ise $809 \mathrm{~nm}$ 1şıma yapabilen GaAlAs laserin 72.saatin sonunda hücrelerin metabolik aktivitelerinde artışa sebep olduğu, dolayısıyla hücre çoğalmasını tetiklediği gözlenmiştir (Kreisler et al., 2003). Gingival fibroblast hücrelerde ise 24 saat sonunda hücrelerin çoğaldı̆̆ 1 , ancak 48 ve 72 . saatlerde azaldığ 1 bildirilmiştir (Kreisler et al., 2002).

Sonuç olarak, literatürde halen birbiri ile uyumlu olmayan sonuçları içeren laser uygulamalarına dair yayınlar mevcuttur. Kesin bir yargıya varılmadan önce bu farklı sonuçların, birçok hücre dizisi üzerinde, farklı 1şık kaynakları kullanılarak, iyi dizayn edilen araştırmalarda, hücresel mekanizmalara ait bir çok parametre ile beraber değerlendirilmesi gereklidir.

Teşekkür: Boğaziçi Üniversitesi Biyomedikal Mühendisliği Enstitüsü Öğretim Üyesi Prof. Dr. Murat Gülsoy’a Biyofotonik Laboratuvarı ve Doç.Dr. Bora Garipcan'a Hücre Kültürü Laboratuvarı imkanlarından faydalanmamı sağladıkları için teşekkür ederim.

\section{Kaynaklar}

Oniszczuk, A., Wojtunik-Kulesza, K.A., Oniszczuk, T., Kasprzak, K. 2016. "The potential of photodynamic therapy (PDT) Experimental investigations and clinical use", Biomedicine and Pharmacotherapy, 83: 912929.

Topaloğlu, N., Güney, M., Aysan, N.,Gülsoy, M., 2015. "The role of reactive oxygen species in the bacterial phtodynamic treatment: photoinactivation vs proliferation", 
Letters in Applied Microbiology, 62(3):230236.

Zecha, J.A.E.M., Raber-Durlacher, J.E., Nair, R.G., Epstein, J.B., Elad, S., Hamblin, M.R., Barasch, A., Migliorati, C.A., Milstein, D.M.J., Genot, M-T., Lansaat, L., van der Brink, R., Arnabat-Dominguez, J., van der Molen, L., Jacobi, I., van Diessen, J., de Lange, J., Smeele, L.E., Schubert, M.M., Bensadoun, R-J. 2016. "Low-level laser therapy/photobiomodulation in the management of side effects of chemoradiation therapy in head and neck cancer: part 2: proposed applications and treatment protocols" Supportive Care in Cancer, 24 (6):2781-2792.

Yu, W., Wang, Y., Wang, J., Fang, W., Xia, K., Shao, J., Wu, M.,Liu, B., Liang, C., Ye, C., Tao, H., 2017. "A review and Outlook in the treatment osteosarcoma and other deep tumors with photodynamic therapy: from basic to deep" Oncotarget, 13 (24): 3983339848.

Posten, W., Wrone, D., Dover, J., Arndt, K, Silapunt, S., Alam, M., 2005. "low level Laser therapy for wound healing", Dermatologic Surgery, 31(3):334-340.

Schartinger, V.H., Galvan, O., Riechelmann, H., Duda, J., 2012. "Differential responses of fibroblasts, non-neoplastic epithelial cells, and oral carcinoma cells to low-level laser therapy" Supportive Care in Cancer, 20 (3): 523-529.

AlGhamdi, K.M., Kumar, A., Moussa, N.A., 2012. "Low-level laser therapy: A useful technique for enhancing the proliferation of various cultured cells", Lasers in Medical Science, 27 (1): 237-249.

Xu, D., Ke, Y., Jiang, X., Cai, Y., Peng, Y., $\mathrm{Li}, \mathrm{Y}$., 2010. "In vitro photodynamic therapy on human U251 glioma cells with a novel photosensitizer ZnPcS4-BSA". British Journal of Neurosurgery, 24, 660-665.

Ottaviani, G., Martinelli, V., Rupel, K., Caronni, N., Naseem, A., Zandonà, L, Perinetti, G., Gobbo, M., Di Lenarda, R., Bussani, R., Benvenuti, F., Giacca,
M., Biasotto, M., Zacchigna, S., 2016. "Laser Therapy Inhibits Tumor Growth in Mice by Promoting Immune Surveillance and Vessel Normalization" EBioMedicine., 11:165-172. doi: 10.1016/j.ebiom.2016.07.028.

Dastanpour, S., Beitollahi, J.M., Saber, K., 2015. "The effect of Low-level Laser threapy on Human Leukemic Cells", J Lasers Med Sci., 6(2): 74-79.

Powell, K., Low, P., McDonnell, P.A., Laakso, E-L., Ralph, S.J., 2010. “The Effect of Laser Irradiation on Proliferation of Human Breast Carcinoma, Melanoma, and Immortalized Mammary Epithelial Cells", Photomedicine and Laser Surgery, 28, No. 1, https://doi.org/10.1089/pho.2008.2445.

Kreisler M., Christoffers A.B., Willershausen, B., d'Hoedt, B., 2003. "Low-level 809 nm GaAlAs laser irradiation increases the proliferation rate of human laryngeal carcinoma cells in vitro." Lasers Med Sci.; 18(2):100-3.

Kreisler, M., Christoffers, A.B., Al-Haj, H., Willershausen, B. d'Hoedt, B., 2002. "Low level $809-\mathrm{nm}$ diode laser-induced in vitro stimulation of the proliferation of human gingival fibroblasts" Lasers in Surgery and Medicine, 30:365-369. 